\title{
EFFECTS OF DIFFERENT CLIMATIC CONDITIONS ON BIRCH AND POPLAR SEEDLINGS
}

Valda GUDYNAITE்-FRANCKEVIČIENĖ, Institute of Forestry, Lithuanian Research Centre for Agriculture and Forestry, Liepu 1, Girionys, 53101 Kaunas district, Lithuania, gudynaitev@gmail.com (corresponding author)

Valda ARAMINIENE், Institute of Forestry, Lithuanian Research Centre for Agriculture and Forestry, Liepų 1, Girionys, 53101 Kaunas district, Lithuania, valda.araminiene@mi.lt

Iveta VARNAGIRYTE்-KABAŠINSKIENĖ, Institute of Forestry, Lithuanian Research Centre for Agriculture and Forestry, Liepu 1, Girionys, LT-53101 Kaunas district, Lithuania, iveta.kabasinskiene@ mi.lt

The effects of different climatic conditions on birch (Betula pendula Roth) and poplar (Populus) hybrids seedlings were studied. This study consists of two parts, firstly, an experiment with poplars and, secondly, the experiment with birch seedlings. The aim of this study was to evaluate the growth of birch and poplar seedlings under the current and modelled climatic conditions. Results showed that the simulation of short-term warmer weather conditions and higher $\mathrm{CO}_{2}$ concentration led to more intensive growth of silver birch saplings. Different climatic conditions did not significantly change photosynthetic and transpiration rate of one year old silver birch seedlings. Contrary the transpiration and photosynthesis rate of poplar seedlings significantly depended on drought and clone but not on hybrid. Drought altered the transpiration and photosynthesis intensity, water use efficiency, and correlation among most of the traits. The $P$. maximowiczii $\times P$. trichocarpa, $P$. balsamifera $\times P$. trichocarpa hybrids increased their water use efficiency under the drought conditions and were characterized by faster growth hybrids. The sensitivity of poplar hybrids to UV-B radiation varied and depended on the origin of their parental trees: poplar hybrids from the northern latitudes were more sensitive to the increased UV-B radiation than those of southern origin. The best growth after simulated warm winter was obtained for the P. deltoides $\times$ P. nigra and P. nigra $\times$ P. nigra hybrids, originating from the southern areas. The findings from this experiment are more applicable to young birch and poplar trees, but stress on young trees may be reflected in future tree growth.

Keywords: birch, poplar, climatic conditions, growth, photosynthesis

\section{INTRODUCTION}

Climate change, mostly caused by higher atmospheric temperatures, $\mathrm{CO}_{2}$ concentration, UV-B radiation has an impact on forest tree species, i.e. they change their phenology, growth rate and reduce stand health. Recently, soft broadleaves, as birch and poplars, became more valued tree species and their planting is an important and cost-effective forest management activity. These species are fast-growth and their short rotation stands are important economically grown as wood for pulp production, and ecologically - important for climate change mitigation in a case that their high calorie wood is an important renewable source for bioenergy sector.

In the future bioenergy plantations will become one of the most important biomass sources for energy on a global scale (Berndes et al., 2003, Walle et al., 2007). In short-rotation forestry systems, fast-growing species are grown to attain high yields of biomass (Walle et al., 2007). To meet the needs of raw materials from renewable natural resources on the timber market of the European Union, it is necessary to expand forest plantation areas (Kuiper et al., 1998). The importance of high-yield tree plantations in providing wood products continues to increase at the global scale (Payn et al. 2015). In Europe, over 1 million ha of different tree species plantations have already been established and they produce 8.3 million $\mathrm{m}^{3}$ of wood. The efficiency of plantation forestry depends primarily on the selection of appropriate clones for the given environmental conditions. Most often, poplar and willow are recommended for planting in short-rotation systems (Walle et al., 2007). Some research also was focussed on the use of birch (Ledin, Willebrand, 1996, Hytönen, Issakainen, 2001; Jogiste et al., 2003). Birch and poplar species are ecologically important in the forests of the Northern temperate and Boreal climates. Lithuania is at the northern margins of the natural Populus nigra distribution range, and the Betula pendula is native tree specie in Lithuania.

Climate change is expected to increasingly affect the species composition of Central European forests. Due to the climate change even more frequent are temperature and precipitation extremes resulting in a stressful environmental impact on growing trees (Kattenberg et al., 1996). Global changes have a major impact on all biological processes and can significantly change plant life cycles and functions (Norby, Luo, 2004). The efficiency of forestry depends on the selection of tree species or their hybrids for the given environmental conditions.

Copyright (C 2019 The Authors. Published by Vytautas Magnus University. This is an open-access article distributed under the terms of the Creative Commons Attribution License (CC BY 4.0), which permits unrestricted use, distribution, and reproduction in any medium, provided the original author and source are credited. 
Birch, poplar and poplar hybrids are defined as economically and ecologically promising species for cultivation, especially for the development of intensive short-rotation forestry in Lithuania under the climate change.

The aim of this study was to evaluate the growth of birch and poplar seedlings under the current and modelled climatic conditions. The interpretation of these findings would allow us to predict the growth possibilities and perspectives of fast-growing tree species for a particular species under the changing climate conditions. Despite of many studies on fast-growing birch and poplar species, more detail estimates on different climatic conditions (air temperature, $\mathrm{CO}_{2}$ concentration, drought) impact, as the specific effects, are still lacking.

\section{MATERIAL AND METHODS}

This study consists of two parts, firstly, an experiment with poplars is described, and, secondly, the experiment with birch seedlings is described.

For the first study part, 44 clones and cultivars of three different intraspecific hybrids of poplar $(P$. nigra $\times P$. nigra, $P$. deltoides $\times P$. deltoides, $P$. trichocarpa) and four interspecific hybrids $(P$. deltoides $\times P$. nigra, $P$. deltoides $\times$ $P$. trichocarpa, $P$. maximowiczii $\times P$. trichocarpa, $P$. balsamifera $\times P$. trichocarpa) were used. Poplar clones were vegetatively propagated by shoot cuttings and for two years were grown in 3-liter pots filled with peat substrate in the greenhouse of nursery. An ambient UV-B radiation for hybrid poplars was enhanced by $10-15 \%$ using the UV-B lamps, which were installed above the seedlings. For the trial, 7-10 trees of each clone were used. For the measurement of UVB radiation, the Delta OHM HD 2302.0 light meter was used with LP 471 UVB Probe sensor. Damaged tree leaves were examined on a 5-point scale, where 5 points indicated the healthy leaf and 1 point indicated that the whole leaf was heavily damaged. A warm winter was simulated by keeping hybrid poplar seedlings (7-10 individuals of each clone) in an unheated greenhouse from late autumn to early spring. The temperature in the greenhouse was $5-10^{\circ} \mathrm{C}$ higher than outside. The trees were protected from the wind and sudden changes in temperature, and the humidity was 40-60\%. Summer drought simulated without watering poplar seedlings for two weeks (up to leaf withering stage) in a greenhouse The photosynthetic and transpiration rate, water use efficiency was measured in ambient and summer drought conditions using LI-COR 6400 (LI-COR, Lincoln, NE, USA). For the experiment with poplar seedlings, the height of hybrid poplar seedlings was measured twice: at the beginning of the growing season (April) and at the end (September).

For the second study part, one-year-old silver birch (Betula pendula Roth) seedlings, originated from a naturally regenerated silver birch stand in the southwestern Lithuania $\left(54^{\circ} 51^{\prime} \mathrm{N}, 24^{\circ} 03^{\prime} \mathrm{E}\right)$. The birch seedlings were grown in $4-$ liter pots containing sand and neutralised peat mixture for one vegetation season. The seedlings were watered as needed during the experiments. The substrate contained the optimum nutrition for birch and poplars seedlings. No additional fertilizers were added during the experiments. The birch seedlings were grown in an open field for 2.5 months until the start of the simulation experiment. The seedlings were placed in three closed walk-in indoor chambers $(2.5 \times 2 \times 2 \mathrm{~m})$ with controlled climate for 6 weeks to simulate present atmospheric temperature and $\mathrm{CO}_{2}$ concentration and projected elevated temperatures and $\mathrm{CO}_{2}$. The photoperiod was $14 \mathrm{~h}$ light/10 h dark, air humidity was $75 \%$, and photosynthetic photon flux density was about $200 \mu \mathrm{mol} \mathrm{m}-2 \mathrm{~s}-1$ in all chambers. The light was provided by six natural fluorescent lamps (Philips, Waterproof OPK Natural Daylight LF80 Wattage $2 \times 58$ W/TL-D $58 \mathrm{~W}$ ) and one high pressure sodium lamp (Philips MASTER GreenPower CG T $600 \mathrm{~W}$ ). The birch seedlings were exposed to the different conditions: first chamber (current climatic conditions) - $21{ }^{\circ} \mathrm{C} / 14{ }^{\circ} \mathrm{C}$ day/night, $400 \mathrm{mg} \mathrm{L}^{-1} \mathrm{CO}_{2}$; second chamber (B1 climate change scenario) - 23 ${ }^{\circ} \mathrm{C} / 16{ }^{\circ} \mathrm{C}, 550 \mathrm{mg} \mathrm{L}^{-1} \mathrm{CO}_{2}$ third chamber (A2 climate change scenario) - $25{ }^{\circ} \mathrm{C} / 18{ }^{\circ} \mathrm{C}, 750 \mathrm{mg} \mathrm{L}^{-1} \mathrm{CO}_{2}$. The photoperiod, humidity and photosynthetic photon flux density were automatically adjusted, temperature and $\mathrm{CO}_{2}$ concentration were controlled by the PC-based Environmental Control System (computer software IGSS 9-13175).

For the experiment with birch seedlings, the height of the seedlings was measured twice: at the beginning of the climate simulation experiment (30 June) and at the end, i.e., after 6 weeks of growth in the chambers. The photosynthetic and transpiration rate of six of the remaining leaves per treatment was measured three times with a photosynthetic system LI-COR 6400 on August 10 (after 2, 4 and 6 weeks in the chamber). In each treatment, the mature and visually healthy leaves were measured in the middle part of the canopy.

The normality of the variables was checked using Lilliefors and Kolmogorov-Smirnov tests. The Kruskal-Wallis analysis of variance (ANOVA) test was used to ascertain the significant differences in dry mass between the different treatments. This test is used as a nonparametric alternative to between-groups one-way ANOVA in cases when the data are not normally distributed. Throughout the study, the means are presented with the standard error of the mean $( \pm \mathrm{SE})$. Statistical analyses were conducted using the Statistica 7.0 software at $p<0.05$ in all cases.

\section{RESULTS}

\section{Main changes of birch seedlings induced by different climatic conditions}

Silver birch seedlings were grown in the climatic chambers with different temperature and $\mathrm{CO}_{2}$ concentration for a 6week period. During this period, the growth rate of the seedlings was very similar and did not depend on environmental conditions. The height increment of the seedlings varied between 10.6 and $13.7 \mathrm{~cm}$, irrespective of climatic conditions (Fig. 1). The height increment of birch seedlings grown both at a $23^{\circ} \mathrm{C}$ temperature with $550 \mathrm{ppm} \mathrm{CO}_{2}$ and at $25^{\circ} \mathrm{C}$ with 750 ppm $\mathrm{CO}_{2}$ increased by $1.7-1.9$ times compared to the current atmospheric temperature $\left(21^{\circ} \mathrm{C}\right.$ at day time $)$ and $400 \mathrm{ppm} \mathrm{CO}_{2}$.

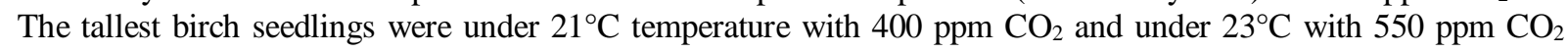
reaching up to a $10 \%$ greater height compared to the plants grown under the $25^{\circ} \mathrm{C}$ temperature and $750 \mathrm{ppm} \mathrm{CO}_{2}(\mathrm{Table} 1)$. 

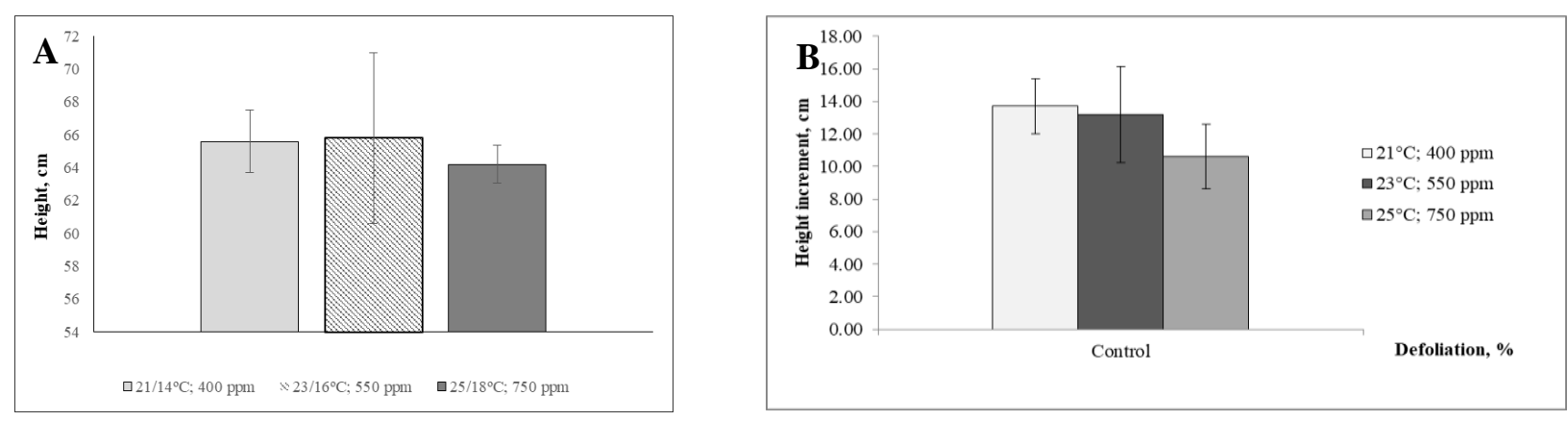

Figure 1. Mean height (A) and height increment (B) of silver birch seedlings after a 6-week growing period at different climatic conditions. Values are given as the mean $\pm \mathrm{SE}(\mathrm{n}=6)$

Photosynthesis rate of birch showed no significant difference under current and elevated temperature and $\mathrm{CO}_{2}$ after 6 weeks in the climate chamber (Table 1). Current temperature up to $21^{\circ} \mathrm{C}$ and $400 \mathrm{ppm} \mathrm{CO}_{2}$ tended to increase the leaf transpiration rate up to $26-34 \%$. Results showed that photosynthesis and transpiration rate decreased during vegetation season.

Table 1. Some physiological parameters in the silver birch leaves. Values are given as the mean $\pm \mathrm{SE}(\mathrm{n}=6)$. Different letters within a row indicate statistically significant differences in the photosynthetic and transpiration rates between treatments $(\mathrm{p}<0.05)$

\begin{tabular}{|c|c|c|c|c|}
\hline Variable & $\begin{array}{l}\text { Climatic } \\
\text { conditions }{ }^{1}\end{array}$ & $\begin{array}{l}2 \text { weeks in } \\
\text { the chamber }\end{array}$ & $\begin{array}{l}4 \text { weeks in } \\
\text { the chamber }\end{array}$ & $\begin{array}{l}6 \text { weeks in } \\
\text { the chamber }\end{array}$ \\
\hline \multirow{3}{*}{ 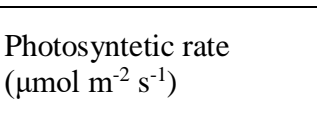 } & $21 / 14^{\circ} \mathrm{C} ; 400 \mathrm{ppm}$ & $6.30 \pm 0.06$ & $5.36 \pm 0.05$ & $3.62 \pm 0.06^{\mathrm{a}}$ \\
\hline & $23 / 16^{\circ} \mathrm{C} ; 550 \mathrm{ppm}$ & $5.79 \pm 0.09$ & $4.39 \pm 0.07$ & $3.36 \pm 0.06^{\mathrm{a}}$ \\
\hline & $25 / 18^{\circ} \mathrm{C} ; 750 \mathrm{ppm}$ & $5.72 \pm 0.08$ & $5.28 \pm 0.04$ & $3.94 \pm 0.05^{\mathrm{a}}$ \\
\hline \multirow{3}{*}{ 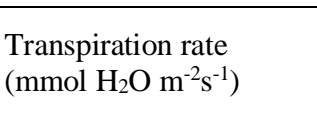 } & $21 / 14^{\circ} \mathrm{C} ; 400 \mathrm{ppm}$ & $1.44 \pm 0.01$ & $0.54 \pm 0.00$ & $0.46 \pm 0.00^{\mathrm{b}}$ \\
\hline & $23 / 16^{\circ} \mathrm{C} ; 550 \mathrm{ppm}$ & $0.97 \pm 0.01$ & $0.53 \pm 0.00$ & $0.30 \pm 0.00^{\mathrm{a}}$ \\
\hline & $25 / 18^{\circ} \mathrm{C} ; 750 \mathrm{ppm}$ & $0.95 \pm 0.01$ & $0.56 \pm 0.00$ & $0.34 \pm 0.00^{\mathrm{a}}$ \\
\hline Water use efficiency & $21 / 14^{\circ} \mathrm{C} ; 400 \mathrm{ppm}$ & $4.42 \pm 0.06$ & $10.02 \pm 0.10$ & $7.78 \pm 0.11$ \\
\hline$\left(\mu \mathrm{mol} \mathrm{CO} 2 \mathrm{~m}^{-2} \mathrm{~s}^{-1} / \mathrm{mmol}\right.$ & $23 / 16^{\circ} \mathrm{C} ; 550 \mathrm{ppm}$ & $6.06 \pm 0.11$ & $8.30 \pm 0.14$ & $10.48 \pm 0.42$ \\
\hline $\left.\mathrm{H}_{2} \mathrm{Om}^{-2} \mathrm{~s}^{-1}\right)$ & $25 / 18^{\circ} \mathrm{C} ; 750 \mathrm{ppm}$ & $6.05 \pm 0.08$ & $9.56 \pm 0.10$ & $11.66 \pm 0,14$ \\
\hline
\end{tabular}

No clear relationship between water use efficiency and different climatic conditions was found. Since tree growth responded to several factors at the same time, it was difficult to find only one predisposing factor, or they could act synergistically.

Sensitivity of Populus hybrids to $U V$-B radiation and avoidance of growth disturbances caused by warm winters

The effect of warm winter, as a stress factor, on the growth in height and diameter was not significant (Table 2). However, hybrid effect on the tree diameter was significant $(P<0.001)$ but no effect on height was found.

Table 2. Results from joint mixed linear model analysis of variance traits of hybrid Populus clones of simulated warm winter: $F$-criteria and probability of fixed effects, and variance components and their standart errors for random effects as percent of the total random variation. Level of significance of effects is denoted by: *, $0.01<P<0.05 ; * *, 0.001<P<0.01 ; * * *, P<0.001$.

\begin{tabular}{|c|c|c|c|c|c|c|c|c|c|c|c|}
\hline \multirow{3}{*}{ Trait* } & \multicolumn{4}{|c|}{ Random effects } & \multicolumn{7}{|c|}{ Fixed effects } \\
\hline & \multicolumn{2}{|l|}{ Clones, \% } & \multicolumn{2}{|c|}{$\begin{array}{c}\text { Clones } \times \text { site } \\
\% \\
\end{array}$} & \multicolumn{3}{|c|}{ Hybrids } & \multicolumn{2}{|c|}{ Hybrids $\times$ site } & \multicolumn{2}{|r|}{ Site } \\
\hline & & & & & $\bar{F}$ & $\bar{P}$ & & $\bar{F}$ & $\bar{P}$ & $\bar{F}$ & $\bar{P}$ \\
\hline Dr & $3.69 \pm 3.81$ & $*$ & $11.2 \pm 4.44$ & $* *$ & 5.84 & $<0.001$ & $* * *$ & 1.24 & 0.311 & . 0.00 & 0.953 \\
\hline $\mathrm{Hr}$ & $10.73 \pm 5.35$ & . & $11.0 \pm 4.31$ & $* *$ & 1.00 & 0.441 & . & 0.85 & 0.538 & . $\quad 0.04$ & 0.849 \\
\hline
\end{tabular}

*Dr - diameter in autumn, cm; $\mathrm{Hr}$ - height in autumn, $\mathrm{cm}$.

In the control, the largest stem diameter was measured for the $P$. deltoides $\times P$. trichocarpa, $P$. maximowiczii $\times P$. trichocarpa hybrids, and the smallest - for $P$. deltoides $\times P$. nigra (Fig. 2). After a warm winter, the reduced growth in diameter for the $P$. deltoides $\times P$. trichocarpa, $P$. maximowiczii $\times P$. trichocarpa hybrids was found. Mean diameter of the remaining hybrids at the end of the growing season, followed by a warm winter stress, was higher than that of trees growing under the control conditions. 


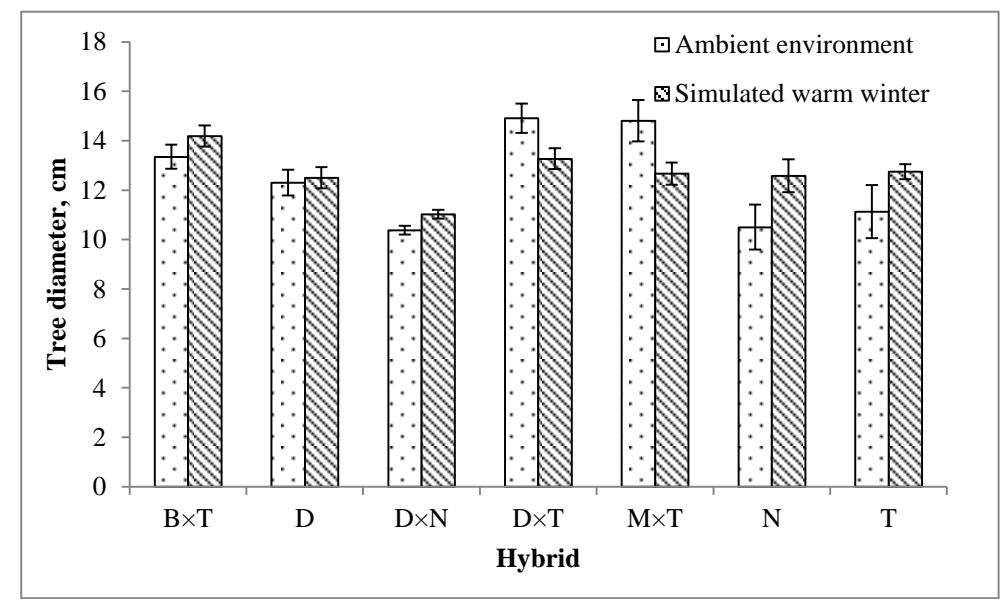

Figure 2. Mean diameter of hybrids affected by simulated warm winter and tested in control (ambient) environment at the end of growing season. ${ }^{*} \mathrm{~B} \times \mathrm{T}-P$. balsamifera $\times P$. trichocarpa, $\mathrm{D} \times \mathrm{N}-P$. deltoides $\times P$. nigra, $\mathrm{D} \times \mathrm{T}-P$. deltoides $\times P$. trichocarpa, $\mathrm{M} \times \mathrm{T}$ $-P$. maximowiczii $\times P$. trichocarpa, $\mathrm{N}-P$. nigra $\times$ P. nigra, D $-P$. deltoides $\times P$. deltoides, $\mathrm{T}-P$. trichocarpa $\times P$. trichocarpa.

Under the control conditions, the $P$. deltoides $\times P$. trichocarpa and $P$. maximowiczii $\times P$. trichocarpa hybrids were highest at the end of the growing season, while the intraspecific $P$. deltoides $\times P$. deltoides and $P$. nigra $\times P$. nigra hybrids were the lowest. A warm winter effect on the mean height of trees was minimal for the $P$. deltoides $\times P$. deltoides, $P$. deltoides $\times P$. nigra and $P$. balsamifera $\times P$. trichocarpa hybrids. After a warm winter, losses of growth in height were recorded for the $P$. deltoides $\times P$. trichocarpa, $P$. maximowiczii $\times P$. trichocarpa and $P$. deltoides $\times P$. deltoides hybrids. The biggest eustress experienced the $P$. nigra $\times P$. nigra and $P$. trichocarpa $\times P$. trichocarpa hybrids - their mean height increased the most. $P$. nigra growing at the northern margins of its natural range easily adapted to warm winter conditions and its mean height was higher than that in the control conditions.

The most damaged by UV-B radiation were the leaves of the $P$. balsamifera $\times$ P. trichocarpa and $P$. maximowiczii $\times P$. trichocarpa hybrids (Fig. 3.). Both hybrids are characterized by a rapid growth in the field trials. In the test under controlled conditions, the hybrids experienced significant growth losses due to spring frosts and summer drought. The $P$. maximowiczii $\times P$. trichocarpa hybrid also suffered from warm winter. All hybrids from the northern sites of origin experienced more intensive leaf damages than hybrids from the southern sites of origin. After UV radiation treatment the healthiest leaves were observed for the P. nigra $\times$ P. nigra and P. deltoides $\times$ P. nigra hybrids.

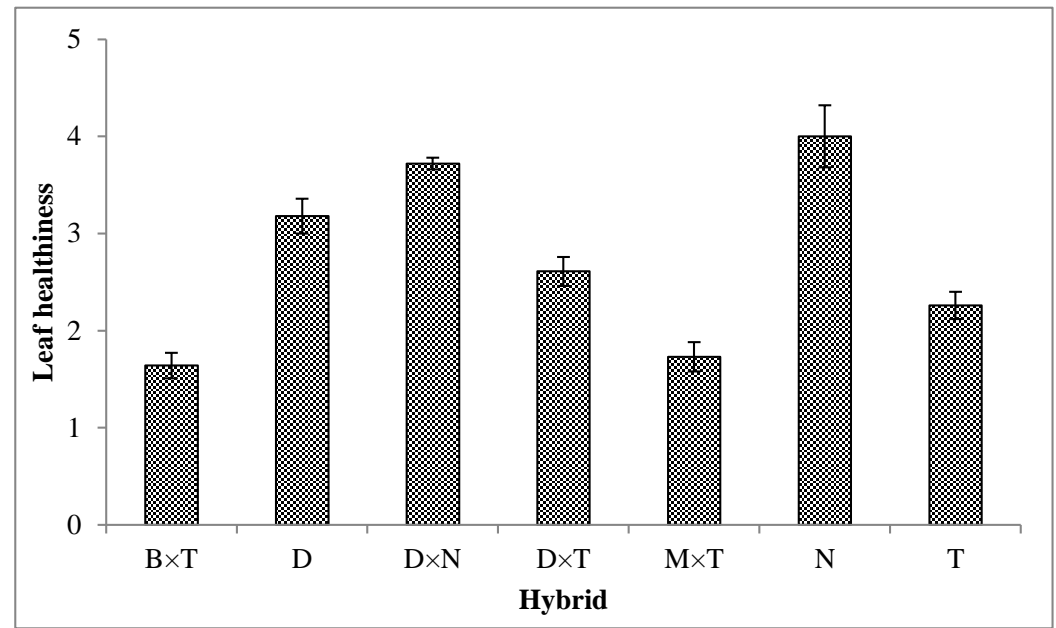

Figure 3. Leaf healthiness (5 - healthy leaf, 1 - the whole leaf is heavily damaged) of Populus hybrids after UV-B treatment. Hybrid type abbreviations explained in Fig.2.

Under normal environmental conditions (the control), the most active transpiration was observed for $P$. deltoides $\times P$. deltoides $\left(2.82 \pm 0.21 \mu \mathrm{mol} \mathrm{m} \mathrm{m}^{-2} \mathrm{~s}^{-1}\right), P$. balsamifera $\times P$. trichocarpa $\left(2.38 \pm 0.18 \mu \mathrm{mol} \mathrm{m}^{-2} \mathrm{~s}^{-1}\right)$ hybrids, while the lowest transpiration intensity was found for $P$. maximowiczii $\times P$. trichocarpa $\left(2.18 \pm 0.09 \mu \mathrm{mol} \mathrm{m}^{-2} \mathrm{~s}^{-1}\right)$ hybrids. Under drought conditions, the most active transpiration was found for the interspecific $P$. deltoides $\times P$. trichocarpa $(2.31 \pm 0.25$ $\left.\mu \mathrm{mol} \mathrm{m} \mathrm{s}^{-1}\right)$ hybrid, while low intensity transpiration was found for P. maximowiczii $\times$ P. trichocarpa $(0.96 \pm 0.14 \mu \mathrm{mol}$ $\mathrm{m}^{-2} \mathrm{~s}^{-1}$ ). An unambiguous evaluation of the obtained transpiration intensity results is impossible as hybrids with the most active transpiration were characterized by different growth in height. P. balsamifera $\times P$. trichocarpa were actively engaged in transpiration and were among the highest ones. Most hybrids (except $P$. nigra $\times$. nigra) lowered their transpiration rate under drought conditions. The most intensive transpiration under normal environmental conditions (the control) for the $P$. deltoides $\times P$. deltoides hybrid under drought conditions decreased drastically - from $2.82 \mu \mathrm{mol} \mathrm{m} \mathrm{m}^{-2} \mathrm{~s}^{-}$ ${ }^{1}$ to $1.45 \mu \mathrm{mol} \mathrm{m} \mathrm{m}^{-2} \mathrm{~s}^{-1}$. The highest intensity of photosynthesis in the control was found for the $P$. nigra $\times P$. nigra hybrid 
$-4.44 \mu \mathrm{mol} \mathrm{m} \mathrm{m}^{-2} \mathrm{~s}^{-1}$, and the lowest intensity - for $P$. maximowiczii $\times P$. trichocarpa $\left(2.89 \pm 0.44 \mu \mathrm{mol} \mathrm{m}^{-2} \mathrm{~s}^{-1}\right)$. Under drought conditions, photosynthesis was intensified by all hybrids, especially by $P$. nigra $\times$ P. nigra $\left(7.38 \pm 0.79 \mu \mathrm{mol} \mathrm{\textrm {m } ^ { - 2 }}\right.$

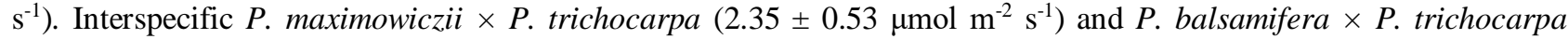
$\left(2.44 \pm 0.41 \mu \mathrm{mol} \mathrm{m}^{-2} \mathrm{~s}^{-1}\right)$ hybrids under drought conditions conducted photosynthesis extensively. These hybrids under drought conditions conducted photosynthesis the least intensively among all tested hybrids. The highest water use efficiency (WUE) under normal climatic conditions was determined for the P. maximowiczii $\times$ P. trichocarpa $(4.46 \pm 1.33$ $\left.\mu \mathrm{mol} \mathrm{mmol}{ }^{-1}\right)$, P. balsamifera $\times$ P. trichocarpa $\left(4.11 \pm 1.87 \mu \mathrm{mol} \mathrm{mmol}^{-1}\right)$. All the hybrids had not only high WUE values but also high among-tree variation. The highest WUE value under drought conditions was obtained for the $P$. deltoides $\times$ $P$. nigra hybrids, and the lowest WUE value - for $P$. maximowiczii $\times$ P. trichocarpa.

\section{DISCUSSION}

This study was set out with the aim to assess the effects of different climatic conditions on birch and poplar seedlings. The results of this study indicate that in general the higher atmospheric temperature in combination with increased $\mathrm{CO}_{2}$ tended to intensify the growth of silver birch seedlings. Generally, birch trees are defined as a pioneer species, typically fast-growing and resistant to natural disturbances, including drought and wind (Fischer et al., 2002; Navasaitis, 2003; Hynynen et al., 2010). To grow well they must have a good supply of light and the trees must be able to develop their crowns without competition from neighbouring trees. B. pendula trees prefer fertile mineral soils with good supply of water and do not grow well on dry or wet soils (Elowson, 1996). In a case of climate warming, several impacts on birch seedlings could be noticed. The data obtained in this study did not show a significantly positive impact of changed climatic conditions on photosynthetic rate of birch seedlings when the ambient temperature was higher than $21^{\circ} \mathrm{C}$, even for a short time. Also, there were no significant changes in height increment likely due to very short study period. Otherwise, the obtained results could not be directly applied to older birch trees because their growth potential, physiological processes, root system development and nutrient reserves differ from the seedlings. Older trees also tend to have higher adaptability to environmental factors, but any stress incurred at a young age may be reflected in later growth processes in older stands

After a warm winter treatment there were no clear differences between poplars of the southern and northern origin: their response to warm winter was insignificantly dependent on the site of origin. Crossbreeding of different hybrids from different adaptive environments disbalances genotypically controlled adaptive preferences and makes it difficult to predict ecological behaviour of the offspring according to the ecological adaptation preferences of their parent trees. Studies of pioneer species show that populations growing in optimal conditions have higher adaptability (Hill et al., 1998). Characterized by a better growth in warm winter conditions $P$. balsamifera $\times P$. trichocarpa and $P$. deltoides $\times P$. nigra had a pronounced sensitivity to spring frosts, which increased the possibility of freeze. It was shown, that temporary peaks of temperature (lasting for few days to weeks) increase the sensitivity of trees to frost and cold (Pagter, Arora, 2013). Early leaf expansion and the following frosts particularly increase the risk of defoliation (Fairweather et al., 2008).

Sensitivity to UV-B is preconditioned not only by the origin of the tree but also gender, interaction with other stressors (temperature, irrigation regime) (Drilias et al., 1997, Zhao et al., 2012, Strømme et al., 2014). It is known that there is a significant effect of UV-B and temperature interaction on poplar bud set (Strømme et al., 2014). A more intensive UV-B radiation determines earlier growth cessation and bud set. Natural ranges of distribution of $P$. nigra $\times P$. nigra and $P$. deltoides $\times P$. nigra hybrids are characterized by higher temperatures and lower water content. Therefore, in clonal trials of this study, they showed the worst performance. The study by Duan et al. (2008) confirms that the negative effect of UV-B on poplar growth is minimal or non-existent under drought conditions.

The $P$. nigra $\times$ P. nigra hybrid, conducting the most intensive photosynthesis in the control, had the lowest height. This can be explained by a low value of leaf area index and low mean leaf area. Similar results were obtained by Barigah et al. (1994) for the cultivar Robusta of the P. deltoides $\times$ P. nigra hybrid. Different hybrids exhibit different strategy to combat the stressor, i.e. drought. WUE of the majority of hybrids increased under drought conditions. This tendency was also shown by Yin et al. (2005) in China regarding other poplar species. Photosynthesis is regulated by different factors such as leaf temperature and $\mathrm{CO}_{2}$ availability, which were included in the photosynthesis model by Karlberg et al. (2006). Elevated atmospheric $\mathrm{CO}_{2}$ tends to increase the rate of photosynthetic carbon fixation by leaves. For example, Ainsworth and Rogers (2007) reported that leaf photosynthetic rates in plants grown at elevated $\mathrm{CO}_{2}\left(475-600 \mathrm{mg} \mathrm{L}^{-1}\right)$ increased by $40 \%$.

\section{CONCLUSIONS}

- The simulation of short-term warmer weather conditions and higher $\mathrm{CO}_{2}$ concentration led to more intensive growth of silver birch saplings. The height increment of birch seedlings varied between 10.6 and $13.7 \mathrm{~cm}$, irrespective of climatic conditions.

- The climatic conditions did not significantly change photosynthetic rate of silver birch seedlings during 6 weeks period but current temperature tended to increase the leaf transpiration rate up to $26-34 \%$.

- The transpiration and photosynthesis of poplar seedlings significantly depended on drought and clone but not on hybrid. Drought altered the transpiration and photosynthesis intensity, water use efficiency, and correlation among most of the traits. The P. maximowiczii $\times$ P. trichocarpa, $P$. balsamifera $\times P$. trichocarpa hybrids increased their water use efficiency under the drought conditions and were characterized as faster growth hybrids. 
- The sensitivity of hybrids to UV-B radiation varied and depended on the origin of their parental trees: poplar hybrids from the northern latitudes were more sensitive to the increased UV-B radiation than those of southern origin. The best growth after simulated warm winter was obtained for the $P$. deltoides $\times P$. nigra and $P$. nigra $\times P$. nigra hybrids, originating from the southern areas.

Acknowledgement. The paper presents research findings, which have been obtained through the Long-term research program "Sustainable forestry and global changes" implemented by Lithuanian Research Centre for Agriculture and Forestry, Institute of Forestry.

\section{REFERENCES}

1. Ainsworth EA, Rogers A. 2007. The response of photosynthesis and stomatal conductance to rising $\left(\mathrm{CO}_{2}\right)$ : mechanisms and environmental interactions. Plant Cell Environ, Vol. 30, pp. 258-270. https://doi.org/10.1111/j.1365-3040.2007.01641.x

2. Barigah T.S., Saugier B., Mousseau M., Guittet J., Ceulemans R. 1994. Photo-synthesis, leaf area and productivity of 5 poplar clones during their establishment year. In annales des sciences forestières, EDP Sciences, Vol. 51(6), pp. 613-625. https://doi.org/10.1051/forest:19940607

3. Berndes G., Hoogwijk M., van den Broek R. 2003. The contribution of biomass in the future global energy supply: a review of 17 studies. Biomass and Bioenergy, Vol. 25, pp. 1-28. https://doi.org/10.1016/S0961-9534(02)00185-X

4. Drilias P., Karabourniotis G., Levizou E., Nikolopoulos D., Petropoulou Y., Ma-netas Y. 1997. The effects of enhanced UV-B radiation on the Mediterranean everg-reen sclerophyll Nerium oleander depend on the extent of summer precipita-tion. Functional Plant Biology, Vol. 24(3), pp. 301-306. https://doi.org/10.1071/PP96105

5. Duan B., Xuan Z., Zhang X., Korpelainen H., Li C. 2008. Interactions between drought, ABA application and supplemental UVB in Populus yunnanensis. Physiolo-gia plantarum, Vol. 134(2), pp. 257-269. https://doi.org/10.1111/j.1399-3054.2008.01128.X

6. Elowson S. 1996. Birch-a high producing species. In: Perttu K., Koppel A. (eds.). Short rotation willow coppice for renewable energy and improved environment. Uppsala. p. 107.

7. Ericsson T. 1981. Effects of varied nitrogen stress on growth and nutrition in three Salix clones. Physiologia Plantarum, Vol. 51, pp. 423-429. https://doi.org/10.1111/j.1399-3054.1981.tb05580.x

8. Fairweather M. L., Geils B. W., Manthei M. 2008. Aspen decline on the Coconino national forest. In: McWilliams, M. (Compiler), Proceedings of the 55th Western International Forest Disease Work Conference, Oregon Department of Forestry, Salem, OR, pp. 53-62.

9. Fischer A., Lindner M., Abs C., Lasch,P. 2002 Vegetation dynamics in central European forest ecosystems (near-natural as well as managed) after storm events. Folia Geobot, Vol. 37, pp. 17-32. https://doi.org/10.1007/BF02803188

10. Hill J., Becker H.C., Tigerstedt P.M.A. 1998. Plant Breeding. Series 4: Quantitative and Ecological Aspects of Plant Breeding. Chapman \& Hall, p. 275. https://doi.org/10.1007/978-94-011-5830-5

11. Hynynen J., Niemistö P., Viherä-Aarnio A., Brunner A., Hein S., Velling P. 2010. Silviculture of birch (Betula pendula Roth and Betula pubescens Ehrh.) in northern Europe. Forestry, Vol. 83(1), pp. 103-119. https://doi.org/10.1093/forestry/cpp035

12. Hytönen, J., Issakainen, J. 2001. Effect of repeated harvesting on biomass production and sprouting of Betula pubescens. Biomass and Bioenergy, Vol. 20, pp. 237-245. https://doi.org/10.1016/S0961-9534(00)00083-0

13. Yin C., Wang X., Duan B., Luo J., Li C., 2005. Early growth, dry matter allocation and water use efficiency of two sympatric Populus species as affected by water stress. Environmental and Experimental Botany, Vol. 53(3), pp. 315-322. https://doi.org/10.1016/j.envexpbot.2004.04.007

14. Jogiste K., Vares A., Sendrós M. 2003. Restoration of former agricultural fiels in Estonia: comparative growth of planted and naturally regenerated birch. Forestry, Vol. 76, pp. 209-219. https://doi.org/10.1093/forestry/76.2.209

15. Karlberg L, Ben-Gal A, Jansson P, Shani,U. 2006. Modelling transpiration and growth in salinity-stressed tomato under different climatic conditions. Ecological Modelling, Vol. 190(1-2), pp. 15-40. https://doi.org/10.1016/j.ecolmodel.2005.04.015

16. Kattenberg A., Giorgi F, Grassl H, Meehl G.A, Mitchell J.F.B., Stouffer R.J., To-kioka T., Weaver A.J, Wigley T.M.L. 1996. Climate models - Projections of future climate. Cambridge University Press, pp. 289-357.

17. Kuiper L.C., Sikkema R., Stolp J.A.N. 1998. Establishment needs for short rotation forestry in the EU to meet the goals of the Commission's white paper on renewable energy. Biomass \& Bioenergy, Vol. 15, pp. 451-456 https://doi.org/10.1016/S09619534(98)00058-0

18. Ledin S., Willebrand E. 1996. Handbook on how to grow short rotation forests. Swedish University of Agricultural Sciences, Department of Short Rotation Forestry.

19. Navasaitis M., Ozolinčius R., Smaliukas D., Balevičienè J. 2003. Lietuvos dendroflora. Monografija. Kaunas: Lututė, $160-187$. (In Lithuanian).

20. Norby R. J., Luo Y. 2004. Evaluating ecosystem responses to rising atmospheric $\mathrm{CO}_{2}$ and global warming in a multi-factor world. New Phytologist, Vol. 162, pp. 281-293 https://doi.org/10.1111/j.1469-8137.2004.01047.x.

21. Pagter M., Arora R. 2013. Winter survival and deacclimation of perennials under warming climate: physiological perspectives. Physiologia plantarum, Vol. 147(1), pp. 75-87. https://doi.org/10.1111/j.1399-3054.2012.01650.x

22. Payn T., Kollert W., Liu S., Rodriguez L., Neves Silva L., Wingfield M., Michel-Carnus J., Orazio C., Freer-Smith P. 2015. Changes in planted forests and future global implications. Forest Ecology and Management, Vol. 352, pp. 57-67. https://doi.org/10.1016/j.foreco.2015.06.021 
23. Strømme C.B., Julkunen-Tiitto R., Krishna U., Lavola A., Olsen J.E., Nybakken L. 2014. UV-B and temperature enhancement affect spring and autumn phenology in Populus tremula. Plant, cell \& environment, Vol. 38(5), pp. 867-877. https://doi.org/10.1111/pce.12338

24. Walle I.V., Camp N. V., de Casteele L. V., Verheyen K., Lemeur R. 2007. Short-rotation forestry of birch, maple, poplar and willow in Flanders (Belgium) I-Biomass productionafter 4 years of tree growth. Biomass and Bioenergy, Vol. 31 (5), pp. 267275. https://doi.org/10.1016/j.biombioe.2007.01.019

25. Zhao H., Li Y., Zhang X., Korpelainen H., Li C. 2012. Sex-related and stage-dependent source-to-sink transition in Populus cathayana grown at elevated $\mathrm{CO}_{2}$ and elevated temperature. Tree Physiology, Vol. 32, pp. $1325-1338$. https://doi.org/10.1093/treephys/tps074 